\title{
Correction to: The possibilities and practicalities of professional learning in support of Indigenous student experiences in schooling: A systematic review
}

\author{
Greg Vass $^{1}$ (D) $\cdot$ Kevin Lowe $^{2} \cdot$ Cathie Burgess $^{3} \cdot$ Neil Harrison $^{2} \cdot$ Nikki Moodie $^{4}$
}

Published online: 11 April 2019

(c) The Australian Association for Research in Education, Inc. 2019

\section{Correction to: The Australian Educational Researcher https://doi.org/10.1007/s13384-019-00313-7}

In the original publication of the article, the author group was incorrectly published without the co-authors. The correct author group is "Greg Vass, Kevin Lowe, Cathie Burgess, Neil Harrison, Nikki Moodie".

Kevin Lowe is a Gubbi Gubbi man from southeast Queensland. He is a currently a Post-Doctoral Fellow at Macquarie University working on an innovative, community focused research project on developing a model of sustainable improvement in Aboriginal education. Kevin has had extensive, experience across the education sector, including teaching, TAFE administrator, University lecturer, and Inspector, Aboriginal Education in the NSW Board of Studies. Kevin has expertise in working with establishing successful programs with Aboriginal community organisations on establishing Aboriginal language policy and curriculum development and its implementation. Over the last 20 years Kevin has led educational projects with Aboriginal communities, schools and education systems that centre on the development of effective school-community learning partnerships. Recently Kevin has worked collaboratively with a team of crossinstitutional academics to review research across key areas of schooling and established the Aboriginal Voices a broad-base, holistic project which is developing a new pedagogic framework for teachers.

The original article can be found online at https://doi.org/10.1007/s13384-019-00313-7.

Greg Vass

g.vass@griffith.edu.au

1 School of Education and Professional Studies, Griffith University, Gold Coast, QLD 4215, Australia

2 Macquarie University, Sydney, Australia

3 University of Sydney, Sydney, Australia

4 University of Melbourne, Melbourne, Australia 
Cathie Burgess coordinates Aboriginal Studies, Aboriginal Community Engagement and the Master of Education: Leadership in Aboriginal Education programs at the University of Sydney. Cathie's research involves community-led initiatives positioning Aboriginal cultural educators as experts through projects such as Learning from Country in the City, Aboriginal Voices: Insights into Aboriginal Education and Redfern Cultural Program.

Neil Harrison is an Associate Professor in the Department of Educational Studies, Macquarie University, Australia. His research focuses on the ways in which Indigenous knowledge of Country can be embedded in the Australian Curriculum. His latest book (together with Juanita Sellwood), Learning and Teaching in Aboriginal and Torres Strait Islander Education (Oxford) is used widely in teacher education programs throughout Australia.

Nikki Moodie is a Senior Lecturer in Indigenous Studies in the School of SocialPolitical Sciences at the University of Melbourne. The focus of her research is Indigenous public policy and the sociology of education, with a specific interest in relationality, networks, and identity.

The original article has been corrected.

Publisher's Note Springer Nature remains neutral with regard to jurisdictional claims in published maps and institutional affiliations 